УДК 577.112.3:633.324 (571.1)

\title{
СОДЕРЖАНИЕ БЕЛКА И АМИНОКИСЛОТ В ЗЕРНЕ ОЗИМЫХ КУЛЬТУР, ПРОИЗРАСТАЮЩИХ НА ТЕРРИТОРИИ ЛЕСОСТЕПИ ЮГО-ВОСТОКА ЗАПАДНОЙ СИБИРИ
}

\author{
(C) Е.П. Кондратенко ${ }^{1}$, О.Б. Константинова ${ }^{1}$, О.М. Соболева ${ }^{1 *}$, Е.А. Ижмулкина ${ }^{1}$, Н.В. Вербицкая ${ }^{1}$, \\ A.C. Cyxux ${ }^{2}$ \\ ${ }^{1}$ Кемеровский государственный сельскохозяйственный институт, \\ ул. Марковцева, 5, Кемерово, 650056 (Россия), e-mail: meer@yandex.ru \\ ${ }^{2}$ Кемеровская государственная медицинская академия, ул. Ворошилова, 22а, \\ 650029 (Россия).
}

\begin{abstract}
Представлены результаты анализа содержания белка и аминокислот в зерне озимой пшеницы, озимой ржи и озимого тритикале, произрастающих на территории лесостепи юго-востока Западной Сибири в зависимости от вида культуры и биологических особенностей сорта. Определены качественный и количественный аминокислотный составы зерна трех видов и восьми сортов озимых злаков. Приведенные данные свидетельствуют о том, что содержание белка и аминокислот в образцах зерна различается в зависимости от видовых и сортовых особенностей культуры. Среди сортов озимой пшеницы наибольшее содержание белка отмечено у сорта Новосибирская $2-13,43 \%$. Среди сортов озимой ржи превосходство за сортом Петровна 1, зерно которого содержит белка больше на 1,44 и 1,64\% по сравнению с сортом иностранной селекции Зу Драйве и гибридом $\left(\mathrm{F}_{1}\right)$ Хеллтоп соответственно. Высоким содержанием белка характеризовались сорта озимого тритикале Алтайская 5 (14,31\%) и Омская (14,08\%). По содержанию всех аминокислот зерно озимой ржи уступает зерну остальных изучаемых культур. Обоснована необходимость обязательного анализа аминокислотного состава зерна продовольственных культур для определения их биологической ценности.

Ключевые слова: сорт, зерно, озимая пшеница, озимая рожь, озимый тритикале, белок, аминокислоты, аминокислотный скор, биологическая ценность.
\end{abstract}

\section{Введение}

Задача получения качественной, экологически чистой и сбалансированной по аминокислотному составу сельскохозяйственной продукции, в частности кормового и продовольственного зерна, в последнее

Кондратенко Екатерина Петровна - профессор кафедры технологии хранения и переработки сельскохозяйственной продукции, доктор сельскохозяйственных наук,

e-mail: kondratenko.e.p@yandex.ru

Константинова Ольга Борисовна - аспирант кафедры технологии хранения и переработки сельскохозяйственной продукции, e-mail: olykk@mail.ru

Соболева Ольга Михайловна - доцент кафедры технологии хранения и переработки сельскохозяйственной продукции, кандидат биологических наук, e-mail: meer@yandex.ru

Ижмулкина Екатерина Александровна - начальник отдела инновационных технологий, e-mail: oit@ksai.ru

Вербицкая Наталья Валерьевна - аспирант кафедры технологии хранения и переработки сельскохозяйственной продукции, e-mail: veniv4d@mail.ru

Сухих Андрей Сергеевич - старший научный сотрудник центральной научно-исследовательской лаборатории, кандидат фармацевтических наук, доцент, e-mail: Suhih_as@list.ru время становится актуальной.

Проблема качества зерна в современной селекции - одна из главных, наряду с продуктивностью. Решение данной задачи возможно на основе использования всех ресурсов повышения качества сельскохозяйственных культур [1]. В сложных агроклиматических условиях Сибири в сельском хозяйстве интенсивного типа все большее значение приобретают хорошо адаптированные к определенным географическим зонам сорта растений. Внедрение адаптированных сортов в сельскохозяйственное производство становится сейчас наиболее эффективным способом увеличения валовых сборов и повышения качества зерна в хозяйствах юго-востока Западной Сибири.

\footnotetext{
* Автор, с которым следует вести переписку.
} 
Содержание белка и аминокислот - одна из важнейших характеристик биологической ценности зерна. Аминокислотный состав используется как биохимический критерий биологической ценности кормов и пищевых продуктов (по суммарному содержанию незаменимых аминокислот). Аминокислоты являются структурными единицами белковых молекул, участвующих во всех процессах, происходящих в организме человека и животных. Без белков невозможны жизнь, рост и развитие организма. Белки выполняют специфические функции в клетке: ферментативные, строительные, регуляторные и др. Уменьшение белка в рационе до 3\% от рекомендуемых норм вызывает нарушение выработки ферментов и, соответственно, усвоение важнейших питательных веществ.

Дефицит протеинов стимулирует поиск новых сортов и гибридов с высоким содержанием протеина, с хорошо сбалансированным аминокислотным составом, которые могли бы быть использованы в селекционных программах для создания новых улучшенных сортов.

В качестве основного белоксодержащего сырья ведущая роль принадлежит зерновым злаковым культурам. В глобальном масштабе около 70\% потребности человечества в белках покрывается за счет зерна - или при непосредственном употреблении в пищу, или опосредованно путем скармливания его животным для производства мяса. Следовательно, запасные белки растений служат основой питания человека. Пшеница, рожь и тритикале - важнейшие зерновые злаковые культуры.

В России озимая пшеница - основная продовольственная культура, площади ее посева по годам колеблются от 8 до 11 млн га, на ее долю приходится от 20 до 24\% валового сбора зерна. Озимая пшеница позволяет решить вопросы продовольственного обеспечения населения. Ее ценность состоит в том, что зерно отличается высоким содержанием белка (14-17\% и более) и углеводов (80\%), она широко используется в хлебопекарной, макаронной, кондитерской промышленности [2] .

Главным производителем ржи является Российская Федерация. Около 30\% производства ржи используется для пищи человека, остальная часть идет на корм для животных. Основное назначение озимой ржи - продовольственное [3]. В зерне ржи, в зависимости от условий выращивания и сорта, содержится 9 17\% белка, 52-63\% крахмала, 1,6-1,9\% жира [4]. Белок озимой ржи по аминокислотному составу более сбалансирован, чем пшеницы и других зерновых культур, он богаче лизином, треонином, фенилаланином и аргинином [5]. Однако зерно ржи характеризуется рядом недостатков, в частности содержит большое количество водорастворимых пентозанов, количество которых в оболочках составляет до $35 \%$, в алейроновом слое - до $15 \%[6,7]$.

Озимый тритикале - ценная кормовая и продовольственная культура. Тритикале сочетает в себе хозяйственно-ценные признаки пшеницы и ржи, отличается повышенной устойчивостью к болезням и неблагоприятным погодным условиям, способен накапливать в зерне большое количество белка. Например, О.И. Босиева с соавт. отмечают, что тритикале на территории Республики Северная Осетия - Алания может накапливать белка до 16\% [8]. В Сибири площади возделывания сортов тритикале в последние годы достигают нескольких десятков тысяч гектаров [9]. По аминокислотному составу белки этой культуры занимают промежуточное положение между белками пшеницы и ржи [10].

Положительные особенности озимых культур обусловливают стремление поиска исследований качества зерна, получаемого на юго-востоке Западной Сибири, в частности в Кемеровской области. На территории области площади посева озимых зерновых злаковых культур в 2013 г. составили 23294 га. Озимые культуры представлены в основном озимой рожью (14186 га), небольшие площади (более 10000 га) занимает озимая пшеница, и в последние годы все шире распространяется сравнительно новая культура - тритикале. Доля ее посева под урожай в 2013 г. составила 3\% озимого клина.

Известно, что количество аминокислот в зависимости от видовых и сортовых особенностей, а также от факторов внешней среды обеспечивает накопление отдельных фракций белковых веществ. Это в конечном итоге и определяет количество и качество формируемых белков. Нераскрытыми остаются вопросы реакции генотипа на накопление белка в зерне озимой пшеницы, озимой ржи и озимого тритикале, произрастающих в гидротермических условиях лесостепи Кемеровской области.

Цель данного исследования - изучение содержание белка и аминокислот в зерне озимой пшеницы, озимой ржи и озимого тритикале, произрастающих в условиях лесостепи юго-востока Западной Сибири. 


\section{Экспериментальная часть}

Объектом исследования служили три новых сорта озимой пшеницы российской селекции - Скипетр (оригинатор Г.М. Полетаев), Новосибирская 2 и Новосибирская 3 (оригинатор - СибНИИРС), два сорта озимой ржи российской селекции - Петровна 1 (оригинатор - СибНИИСХ и торфа), сорт иностранной селекции - Зу Драйве и гибрид первого поколения $\left(\mathrm{F}_{1}\right)$ - Хеллтоп, два сорта озимого тритикале - Алтайская 5 (оригинатор - Алтайский НИИ земледелия и селекции), Омская (оригинатор - СибНИИСХ и торфа). Все изучаемые сорта относятся к среднеспелой группе. Вегетационный период составляет 316-320 суток. Для оценки содержания белка (по ГОСТ 10846-91), в зависимости от биологических особенностей вида и сорта, были взяты образцы зерна разных сортов озимых злаковых зерновых культур, выращенных в одинаковых агроклиматических условиях - территория лесостепной зоны юго-востока Западной Сибири.

Определение аминокислотного состава зерна изучаемых сортов проведено на аминокислотном анализаторе NIR Systems 4500 (США) в лаборатории биологической химии ГНУ СибНИИЖ Россельхозакадемии (Новосибирск).

Качество белка зерна оценивали путем сравнения его аминокислотного состава с аминокислотным составом «идеального» белка с помощью расчета его аминокислотного скора, который осуществляли по формуле:

$$
C=A / H,
$$

где $C$ - скор, \%; $A$ - содержание аминокислоты в белке зерна изучаемого сорта, г/100 г белка; $H$ - содержание аминокислоты в идеальном белке, г/100 г белка (ФАО/ВОЗ, 1973).

Биологическую ценность белка определяли по формуле:

$$
\begin{aligned}
& Б Ц=100-K P A C ; \\
& K P A C=\frac{\sum \Delta P A C}{n},
\end{aligned}
$$

где $\Sigma \triangle P A C$ - разность аминокислотного скора для каждой незаменимой аминокислоты по сравнению с одной из наиболее дефицитных; $n$ - число незаменимых аминокислот.

На основе этого показателя выделяется три уровня качества: высокий (степень отклонения от стандарта) до 15\%; средний - от 16 до 30\%; низкий - выше 31\%, по которым делали заключение о качестве зерна [11].

Для оценки степени варьирования рассчитывали коэффициент вариации, определяющийся как отношение среднеквадратичного отклонения к среднему значению, выраженному в процентах $(V, \%)$.

\section{Результаты и обсуждение}

Анализ качества зерна показал, что более высоким содержанием белка характеризовалось зерно озимого тритикале (14,2\%), меньшим - озимой ржи (10,75\%) (табл. 1). Значение данного показателя варьировало в зерне озимой пшеницы от 11,30 до 13,43\%, озимой ржи - от 10,14 до 11,78\% и озимого тритикале - от 14,18 до $14,31 \%$.

Проявились сортовые отличия по содержанию белка в зерне. По совокупности данного показателя более качественное зерно формировал сорт озимой пшеницы Новосибирская 2, озимой ржи - Петровна 1 и озимого тритикале - Алтайская 5 и Омская, т.е. сорта сибирской селекции (рис. 1).

Данные рисунка 1 наглядно демонстрируют влияние генотипа и видовых особенностей культуры на содержание белка в зерне злаковых растений, так как влияние эдафических и погодных факторов было одинаковым. Среди сортов озимой пшеницы наибольшее содержание белка отмечено у сорта Новосибирская 2 - 13,43\%, что на 0,85 и 2,13 процентных пункта выше, чем у сортов Скипетр и Новосибирская 3. Среди сортов озимой ржи превосходство за сортом Петровна 1, зерно которого содержит белка больше на 1,44 и 1,64\% по сравнению с сортом иностранной селекции Зу Драйве и гибридом ( $\left.\mathrm{F}_{1}\right)$ Хеллтоп соответственно. Высоким содержанием белка характеризовались сорта озимого тритикале Алтайская 5 и Омская 14,31 и $14,08 \%$ соответственно.

Сравнительное изучение аминокислотного состава белков показало, что в среднем по содержанию всех аминокислот зерно озимой ржи уступает зерну остальных изучаемых культур. Суммарное содержание аминокислот больше в сортах озимой пшеницы и озимого тритикале на 0,84 и 1,23\% соответственно (табл. 2). 
Таблица 1. Среднее содержание белка в зерне озимых злаковых культур за период 2012-2013 гг.

\begin{tabular}{c|c|c|c}
\hline \multirow{2}{*}{ Показатель } & \multicolumn{3}{|c}{ Массовая доля, \% } \\
\cline { 2 - 4 } & озимая пшеница & озимая рожь & озимый тритикале \\
\hline Среднее & 12,41 & 10,75 & 14,2 \\
Lim & $11,30-13,43$ & $10,14-11,78$ & $14,08-14,31$ \\
V, \% & 15,86 & 13,92 & 1,6 \\
\hline
\end{tabular}

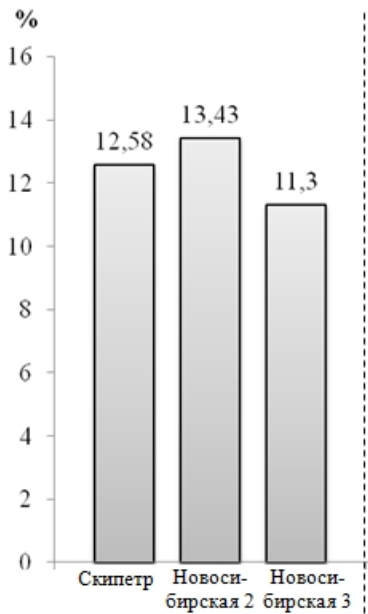

Ознмая пшеннца

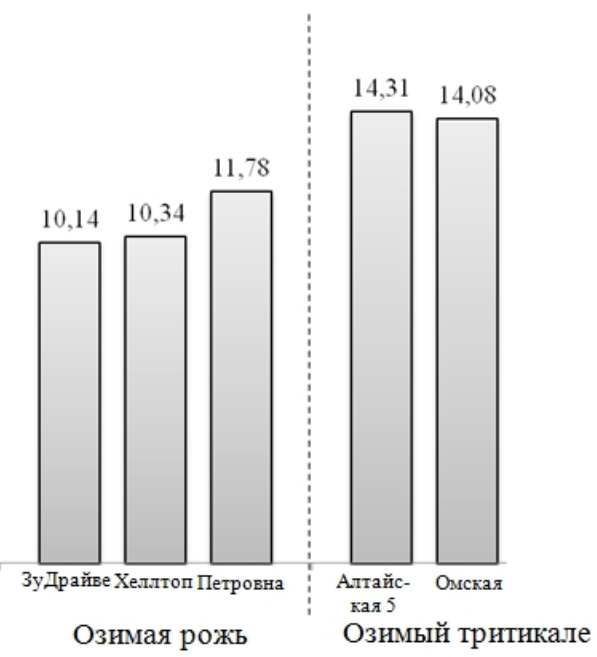

Рис. 1. Среднее содержание белка в зерне сортов озимой пшеницы, озимой ржи, озимого тритикале, \%

Таблица 2. Содержание аминокислот в белке озимых злаковых культур

\begin{tabular}{|c|c|c|c|c|c|c|}
\hline \multirow{3}{*}{ Аминокислоты } & \multicolumn{6}{|c|}{ Содержание аминокислот, г / 100 г } \\
\hline & \multicolumn{2}{|c|}{ озимая пшеница (три сорта) } & \multicolumn{2}{|c|}{$\begin{array}{c}\text { озимая рожь } \\
\text { (два сорта и гибрид) }\end{array}$} & \multicolumn{2}{|c|}{$\begin{array}{c}\text { озимый тритикале } \\
\text { (два сорта) }\end{array}$} \\
\hline & среднее & $\operatorname{Lim}$ & среднее & Lim & среднее & $\operatorname{Lim}$ \\
\hline Аспарагиновая & 0,81 & $0,73-0,86$ & 0,63 & $0,56-0,71$ & 0,76 & $0,69-0,84$ \\
\hline Треонин & 0,77 & $0,64-0,86$ & 0,63 & $0,56-0,70$ & 0,68 & $0,66-0,71$ \\
\hline Серин & 0,78 & $0,71-0,82$ & 0,64 & $0,60-0,68$ & 0,77 & $0,70-0,84$ \\
\hline Глютаминовая & 2,88 & $2,44-3,31$ & 3,50 & $2,82-4,35$ & 3,23 & $3,18-3,28$ \\
\hline Пролин & 0,32 & $0,19-0,51$ & 0,79 & $0,37-1,26$ & 0,94 & $0,65-1,23$ \\
\hline Глицин & 0,67 & $0,63-0,70$ & 0,69 & $0,68-0,70$ & 0,67 & $0,66-0,69$ \\
\hline Аланин & 0,36 & $0,36-0,36$ & 0,25 & $0,22-0,30$ & 0,30 & $0,26-0,34$ \\
\hline Валин & 0,68 & $0,59-0,75$ & 0,61 & $0,54-0,64$ & 0,61 & $0,58-0,65$ \\
\hline Метионин & 0,31 & $0,27-0,34$ & 0,11 & $0,06-0,15$ & 0,24 & $0,19-0,30$ \\
\hline Изолейцин & 0,65 & $0,61-0,70$ & 0,39 & $0,36-0,43$ & 0,56 & $0,53-0,59$ \\
\hline Лейцин & 0,55 & $1,45-1,61$ & 1,52 & $1,17-1,85$ & 1,62 & $1,51-1,73$ \\
\hline Тирозин & 0,28 & $0,26-0,31$ & 0,16 & $0,09-0,26$ & 0,23 & $0,22-0,25$ \\
\hline Фенилаланин & 0,68 & $0,64-0,74$ & 0,34 & $0,18-0,59$ & 0,57 & $0,31-0,83$ \\
\hline Гистидин & 0,27 & $0,26-0,28$ & 0,25 & $0,16-0,33$ & 0,30 & $0,26-0,35$ \\
\hline Лизин & 0,43 & $0,40-0,46$ & 0,24 & $0,18-0,31$ & 0,37 & $0,31-0,42$ \\
\hline Аргинин & 0,23 & $0,17-0,26$ & 0,09 & $0,04-0,15$ & 0,24 & $0,07-0,42$ \\
\hline Триптофан & 0,11 & $0,09-0,12$ & 0,13 & $0,11-0,15$ & 0,13 & $0,12-0,14$ \\
\hline Цистин & 0,24 & $0,19-0,29$ & 0,22 & $0,20-0,24$ & 0,18 & $0,17-0,20$ \\
\hline Сумма & 12,02 & - & 11,18 & - & 12,41 & - \\
\hline
\end{tabular}

Приблизительно одинаковым в зерне озимой пшеницы, озимой ржи и озимого тритикале оказывается содержание глицина $(0,67-0,69$ г/100 г), аланина (0,25-0,36 г/100 г), гистидина $(0,25-0,30$ г/100 г), триптофана $(0,11-0,13$ г/100 г) и цистина $(0,18-0,24$ г/100 г). Содержание триптофана в белках всех озимых культур, произрастающих на территории юго-востока Западной Сибири, низкое. Из литературы известно [12], что эта незаменимая аминокислота является предшественником для образования фитогормона индолилуксусной кислоты (ИДК, indoleacetic acid, IAA) и витамина PР, роль которых в жизни растений общеизвестна. Необеспеченность семян триптофаном может привести к нарушению обмена веществ, снижению их всхожести и жизнеспособности. 
В белках озимой ржи мало аргинина $(0,09$ г/100 г) и метионина $(0,11$ г/100 г), но больше глютаминовой кислоты. По содержанию остальных аминокислот зерно озимой пшеницы, озимой ржи и озимого тритикале существенно различается, особенно по содержанию незаменимых аминокислот - треонина $(0,77 ; 0,63$ и 0,66 г/100 г), метионина $(0,31 ; 0,11$ и 0,24 г/100 г), изолейцина $(0,65 ; 0,39$ и 0,56 г/100 г), лейцина $(0,55 ; 1,52$ и 1,62 г/100 г), фенилаланина (0,68; 0,34 и 0,57 г/10 г), лизина $(0,43 ; 0,24$ и 0,37 г/100 г) соответственно.

Аминокислотный состав зерна озимого тритикале и озимой ржи характеризуется значительным содержанием пролина (0,94 и 0,79 г/100 г) и лейцина (1,62 и 1,52 г/100 г). Устойчивость к засухе и другим неблагоприятным факторам многие исследователи связывают с содержанием пролина в тканях растений, который активно синтезируется в ответ на разные стрессовые воздействия, выступая в качестве осмопротектора [13-17]. Учитывая, что с увеличением накопления пролина растения озимых культур откликаются на воздействия различных неблагоприятных факторов, можно сделать вывод о том, что сорта озимого тритикале и озимой ржи сильнее лимитируются условиями произрастания, чем озимая пшеница. Массовая доля пролина в зерне сортов озимой пшеницы в среднем составляет 0,32 г/100 г, что на 0,62 и 0,47\% меньше, чем у озимого тритикале и озимой ржи соответственно.

Суммарное содержание незаменимых аминокислот в озимой ржи меньше на 16,9\%, чем в зерне озимого тритикале, и на 5\%, чем в зерне озимой пшеницы (табл. 3). Белки злаковых культур неполноценны по ряду незаменимых аминокислот, прежде всего по лизину, метионину, триптофану и треонину. Поэтому при оценке аминокислотной сбалансированности используют эти четыре аминокислоты.

По такой лимитирующей незаменимой аминокислоте, как треонин, зерно озимой пшеницы богаче по сравнению с озимой рожью и озимым тритикале на 18 и 12\%, по метионину - на 64,0 и 22,6\%, по лизину - на 44 и 14\% соответственно. Триптофана накапливается в зерне мало - 0,11-013 г/100 г.

Таким образом, в зерне озимых злаков, произрастающих на территории лесостепи юго-востока Западной Сибири, содержание лимитирующих незаменимых аминокислот у озимой пшеницы больше, чем у остальных изучаемых культур. Наиболее дефицитной по содержанию в белке треонина, метионина и лизина является озимая рожь. У белков всех изучаемых культур первой лимитирующей незаменимой аминокислотой является метионин, второй - лизин.

По суммарному содержанию незаменимых аминокислот белок озимого тритикале несколько отличается от озимой пшеницы, сильнее - от озимой ржи.

Расчет аминокислотного скора показал, что в наибольшей степени требованиям ФАО/ВОЗ соответствуют сорта озимой ржи Петровна 1 и гибрида (F1) Хеллтоп. У этих культур уровень качества зерна приближается к высокому. Биологическая ценность зерна составляет 17 и 18\% соответственно (табл. 4).

Биологическую ценность белка лимитирует незаменимая аминокислота с наименьшим аминокислотным скором. У всех изучаемых сортов озимых культур такой аминокислотой является лизин, аминокислотный скор которой составляет менее 100\%. У сортов озимой пшеницы Новосибирская 2 и Новосибирская 3 содержание лизина высокое в сравнении с другими озимыми культурами - аминокислотный скор составляет 84 и $80 \%$ соответственно. Отмечается низкий аминокислотный скор у сортов озимой ржи, особенно у сорта Петровна 1 - всего $32 \%$.

Результаты определения аминокислотного скора в исследуемых образцах зерна озимых культур показали, что по биологической ценности зерно сортов, произрастающих в условиях лесостепи юго-востока Западной Сибири, имеет средний и низкий уровни качества.

Таблица 3. Содержание незаменимых аминокислот в зерне озимых культур (пшеницы, ржи и тритикале), г / 100 г

\begin{tabular}{l|c|c|c|c|c|c|c}
\hline \multirow{2}{*}{$\begin{array}{c}\text { Незаменимые } \\
\text { аминокислоты }\end{array}$} & $\begin{array}{c}\text { Суточная } \\
\text { потребность, }\end{array}$ & \multicolumn{2}{|c|}{ Озимая пшеница } & \multicolumn{2}{|c|}{ Озимая рожь } & \multicolumn{2}{|c}{ Озимого тритикале } \\
\cline { 3 - 8 } & годержание, & $\begin{array}{c}\text { \% от днев- } \\
\text { г / 100 г }\end{array}$ & $\begin{array}{c}\text { содержание, нормы } \\
\text { г / 100 г }\end{array}$ & $\begin{array}{c}\text { \% от днев- } \\
\text { ной нормы }\end{array}$ & $\begin{array}{c}\text { содержание, } \\
\text { г / 100 г }\end{array}$ & $\begin{array}{c}\% \text { от днев- } \\
\text { ной нормы }\end{array}$ \\
\hline Треонин & 2,5 & 0,77 & 19,3 & 0,63 & 15,8 & 0,68 & 17,0 \\
Валин & 3,5 & 0,68 & 13,6 & 0,61 & 12,2 & 0,61 & 12,2 \\
Метионин & 3 & 0,31 & 8,9 & 0,11 & 3,1 & 0,24 & 6,9 \\
Изолейцин & 3,5 & 0,65 & 16,3 & 0,39 & 9,8 & 0,56 & 14,0 \\
Лейцин & 5 & 0,55 & 7,9 & 1,52 & 21,7 & 1,62 & 23,1 \\
Триптофан & 1 & 0,11 & 11,0 & 0,13 & 13,0 & 0,13 & 13,0 \\
Фенилаланин & 3 & 0,68 & 13,6 & 0,34 & 6,8 & 0,57 & 11,4 \\
Лизин & 4 & 0,43 & 7,8 & 0,24 & 4,4 & 0,37 & 6,7 \\
\hline
\end{tabular}


Таблица 4. Аминокислотный скор озимой пшеницы, озимой ржи и озимого тритикале, \%

\begin{tabular}{|c|c|c|c|c|c|c|c|c|}
\hline \multirow[b]{2}{*}{$\begin{array}{c}\text { Незаменимая ами- } \\
\text { нокислота }\end{array}$} & \multicolumn{3}{|c|}{ Сорта озимой пшеницы } & \multicolumn{3}{|c|}{ Гибрид и сорта озимой ржи } & \multicolumn{2}{|c|}{ Сорта озимого тритикале } \\
\hline & Скипетр & $\begin{array}{l}\text { Новоси- } \\
\text { бирская } 2\end{array}$ & $\begin{array}{c}\text { Новоси- } \\
\text { бирская } 3\end{array}$ & ЗуДрайве & $\begin{array}{c}\text { Хеллтоп } \\
\left(\mathrm{F}_{1}\right)\end{array}$ & Петровна 1 & Алтайская 5 & Омская \\
\hline Валин & 118 & 139 & 130 & 128 & 108 & 128 & 107 & 120 \\
\hline Изолейцин & 152 & 175 & 165 & 97 & 97 & 90 & 135 & 133 \\
\hline Лейцин & 230 & 207 & 227 & 167 & 264 & 220 & 247 & 216 \\
\hline Лизин & 73 & 84 & 80 & 56 & 44 & 32 & 76 & 56 \\
\hline Метионин + цистин & 131 & 162 & 174 & 86 & 100 & 94 & 142 & 103 \\
\hline Треонин & 160 & 215 & 203 & 175 & 140 & 160 & 165 & 177 \\
\hline Триптофан & 120 & 90 & 110 & 130 & 150 & 110 & 120 & 140 \\
\hline $\begin{array}{l}\text { Фенилаланин + } \\
\text { тирозин }\end{array}$ & 150 & 161 & 170 & 142 & 45 & 83 & 180 & 88 \\
\hline $\begin{array}{l}\text { Биологическая цен- } \\
\text { ность белка }(K P A C)\end{array}$ & 31 & 30 & 23 & 33 & 18 & 17 & 29 & 26 \\
\hline
\end{tabular}

Установлено, что самым низким уровнем качества зерна обладает сорт озимой ржи Зу Драйве иностранной селекции. Биологическая ценность его составляет 33\%, что по градации [11] соответствует низкому уровню качества. Зерно сортов низкого качества используют преимущественно на фуражные цели. Например, в Канаде, США и других странах такие сорта не допускаются к районированию [18].

\section{Bblводbl}

В результате проведенных исследований установлено, что качество зерна озимой пшеницы, озимой ржи и озимого тритикале, произрастающих на территории лесостепи юго-востока Западной Сибири, далеко от максимально возможного. Анализ содержания белка и аминокислот показал биосинтетические особенности формирования зерна изучаемых видов и сортов озимых культур.

Зерно изучаемых культур характеризуется различным содержанием белка и его аминокислотным составом. Сравнение качества зерна сортов озимых злаковых культур позволило установить, что сорт озимой пшеницы Новосибирская 3 характеризуется низким содержанием белка (11,3\%), но является наиболее биологически ценным по сравнению с другими изучаемыми сортами - Новосибирская 2 и Скипетр. Низким содержанием белка отличаются сорт озимой ржи иностранной селекции Зу Драйве $(10,14 \%)$ и гибрид $\left(\mathrm{F}_{1}\right)$ Хеллтоп (10,34\%). Однако белок зерна гибрида Хеллтоп имеет более высокую биологическую ценность по сравнению с сортом Зу Драйве. Высокобелковыми оказались сорта озимого тритикале сибирской селекции. В среднем они накапливают белка до 14,2\% и формируют зерно среднего уровня качества. Исходя из вышеизложенного, следует отметить, что изученные сорта озимых злаковых культур, произрастающие на территории лесостепи юго-востока Западной Сибири, не обеспечивают потребность региона в накоплении полноценного белка, а значит, и биологически полноценного питания. Полученные результаты позволяют ближе подойти к пониманию причин получения низкого и среднего качества зерна на исследуемой территории, как к явлению, широко распространенному во многих регионах Российской Федерации, и указывают на новые возможности нормализации метаболических процессов формирующейся зерновки. Учитывая особую значимость зерна как источника белка и незаменимых аминокислот для человека и животных, следует проводить исследования с целью выявления сортов озимых злаковых культур с максимальным содержанием биологически важных веществ. В настоящее время этому вопросу уделяется мало внимания.

\section{Список литературы}

1. Высоцкий В.Г., Яцышина Т.А., Рымаренко Т.В. О методах определения биологической ценности белков // Медицинский реферативный журнал. 1976. №6. С. 24-35.

2. Волков О.В. Влияние продолжительности репродуцирования на урожайность и качество зерна озимой пшеницы // Современные проблемы технологии производства, хранения, переработки и экспертизы сельскохозяйственной продукции : материалы Междунар. науч.-практ. конф. Мичуринск, 2007. Т. 1. С. $43-47$.

3. Корякин В.В., Солодова Ю.П. Динамика посевных площадей озимой ржи и значимость как злаковой культуры в решении продовольственной программы // Вестник ТГУ. 2011. Т. 16, вып. 2. С. 660-662.

4. Белугина Н.О., Блинова Е.В. Источники хозяйственно-ценных признаков озимой ржи // Труды по прикладной ботанике, генетике и селекции. 2006. Т. 162. С. 166-170.

5. Минеев А.В., Дебрецени Б., Мазур Т. Биологическое земледелие и минеральные удобрения. М., 1993. 415 с. 
6. Исмагилов Р.Р., Ахиярова Л.М., Гайсина Л.Ф. Содержание пентозанов в зерне гибридов озимой ржи // Вавиловские чтения : материалы Межд. науч.-практ. конф. Саратов, 2012. С. 89-91.

7. Силин М.А. Ценный кормовой продукт из зерна ржи // Кормопроизводство. 2012. №3. С. 44.

8. Босиева О.И., Плиева Е.А., Джиоева Г.Ф. Содержание белка и аминокислотный состав зерна тритикале // Известия Горского ГАУ. 2011. Т. 48, №2. С. 102-104.

9. Мединский А.В., Степочкин П.И. Изучение озимых тритикале в Сибирском научно-исследовательском институте растениеводства и селекции // Сибирский вестник сельскохозяйственной науки. 2014. №1. С. 32-35.

10. Рядчиков В.Г. Улучшение зерновых белков и их оценка. М., 1998. 368 с.

11. Патент 2198538 (РФ). Способ оценки биологической ценности растительного белка / А.П. Стаценко. БИ. 2001. №8. С. 86.

12. Хелдт Г.В. Биохимия растений : пер. с англ. М., 2011. 471 с.

13. Демин Д.А. Влияние поражения твердой головней на количество и фракционный состав белков в зерне пшеницы // Актуальные проблемы сельскохозяйственной науки и образования : сб. науч. тр. Самара, 2005. Вып. 4. С. 154-157.

14. Gutterman Y. Survival strategies of annual desert plants : Adaptations of desert organisms. Berlin ; New York, 2002. Pp. 1-36.

15. Verbruggen N., Hermans C. Proline accumulation in plants : A. Review // Amino acids. 2008. Vol. 35. Pp. $753-759$.

16. Szabados L., Savoure A. Proline : multifunctionae amino acid // Trends Plant Sci. 2010. Vol. 15. Pp. 89-97.

17. Lehmann S., Funck D., Szabados L., Rentsch D. Proline Metabolism and Transport in Plant Development // Amino acids. 2010. Vol. 39. Pp. 949-962.

18. Брежнев Д.Д., Шмараев Г.Е. Селекция растений в США. М., 1976. 349 с.

Поступило в редакичию 21 мая 2015 2.

После переработки 20 сентября 2015 г. 
Kondratenko E.P. ${ }^{l}$, Konstantinova O.B. ${ }^{l}$, Soboleva O.M..$^{1 *}$, Izhmulkina E.A. ${ }^{l}$, Verbitskaya N.V. ${ }^{1}$, Sukhikh A.S. ${ }^{2}$ THE CONTENT OF PROTEIN AND AMINO ACIDS IN GRAIN OF WINTER CROPS GROWING ON THE TERRITORY OF FOREST-STEPPE SOUTH-EAST OF WESTERN SIBERIA

${ }^{1}$ Kemerovo state agricultural Institute, st. Markovtseva, 5, Kemerovo, 650056 (Russia), e-mail: meer@yandex.ru

${ }^{2}$ Kemerovo state medical Academy, st. Voroshilova, 22 ${ }^{A}$, Kemerovo, 650029 (Russia)

This article presents the results of the analysis of the content of protein and amino acids in grain of winter wheat, winter rye and winter triticale growing on the territory of forest-steppe South-East of Western Siberia depending on the type of culture and biological characteristics of the variety. The qualitative and quantitative amino acid composition of three grain species and 8 varieties of winter cereals. These data indicate that the protein content and amino acids in samples of grains varies depending on species and varietal characteristics of culture. Among winter wheat varieties with the highest protein content was observed in grades 2 and Novosibirsk is 13,43\%. Among the varieties of winter rye for the superiority of the cultivar Petrovna 1 the grain which contains more protein by $1.44 \%$ and $1,64 \%$ compared with the varieties of foreign selection Drive and a hybrid $\left(\mathrm{F}_{1}\right)$ Hilltop respectively. High protein was characterized by varieties of winter triticale of the Altai $5-14,31 \%$ and Omsk $14,08 \%$. The content of all amino acids in the grain of winter rye grain is inferior to the other studied cultures the necessity of the required analysis of the amino acid composition of grain food crops to determine their biological value.

Keywords: grade, grain, winter wheat, winter rye, winter triticale, protein, amino acids, near the amino acid, biological value.

\section{References}

1. Vysotskii V.G., Iatsyshina T.A., Rymarenko T.V. Meditsinskii referativnyi zhurnal, 1976, no. 6, pp. 24-35. (in Russ.).

2. Volkov O.V. Sovremennye problemy tekhnologii proizvodstva, khraneniia, pererabotki $i$ ekspertizy sel'skokhoziaistvennoi produktsii : materialy mezhdunar. nauch.-prakt. konf. [Modern problems of technologies of production, storage, processing and examination of agricultural products : materials of international scientific-practical conference]. Michurinsk, 2007, vol. 1, pp. 43-47. (in Russ.).

3. Koriakin V.V., Solodova Iu.P. Vestnik TGU, 2011, vol. 16, no. 2, pp. 660-662. (in Russ.).

4. Belugina N.O., Blinova E.V. Trudy po prikladnoi botanike, genetike i selektsii, 2006, vol. 162, pp. 166-170. (in Russ.).

5. Mineev A.V., Debretseni B., Mazur T. Biologicheskoe zemledelie i mineral'nye udobreniia. [Biological agriculture and fertilizers]. Moscow, 1993, 415 p. (in Russ.).

6. Ismagilov R.R., Akhiiarova L.M., Gaisina L.F. Vavilovskie chteniia : materialy mezhd. nauch.-prakt. konf. [Vavilov Reading : Materials of the international scientific-practical conference]. Saratov, 2012, pp. 89-91. (in Russ.).

7. Silin M.A. Kormoproizvodstvo, 2012, no. 3, pp. 44. (in Russ.).

8. Bosieva O.I., Plieva E.A., Dzhioeva G.F. Izvestiia Gorskogo GAU, 2011, vol. 48, no. 2, pp. 102-104. (in Russ.).

9. Medinskii A.V., Stepochkin P.I. Sibirskii vestnik sel'skokhoziaistvennoi nauki, 2014, no. 1, pp. 32-35. (in Russ.).

10. Riadchikov V.G. Uluchshenie zernovykh belkov i ikh otsenka. [Improving cereal proteins and their evaluation]. Moscow, 1998, 368 p. (in Russ.).

11. Patent 2198538 (RU). 2001. (in Russ.).

12. Kheldt G.V. Biokhimiia rastenii. [Plant Biochemistry]. Moscow, 2011, 471 p. (in Russ.).

13. Demin D.A. Aktual'nye problemy sel'skokhoziaistvennoi nauki i obrazovaniia : sb. nauch. tr. [Actual problems of agricultural science and education: collection of scientific papers]. Samara, 2005, no. 4, pp. 154-157. (in Russ.).

14. Gutterman Y. Survival strategies of annual desert plants : Adaptations of desert organisms. Berlin ; New York, 2002, pp. 1-36.

15. Verbruggen N., Hermans C. Amino acids, 2008, vol. 35, pp. 753-759.

16. Szabados L., Savoure A. Trends Plant Sci., 2010, vol. 15, pp. 89-97.

17. Lehmann S., Funck D., Szabados L., Rentsch D. Amino acids, 2010, vol. 39, pp. 949-962.

18. Brezhnev D.D., Shmaraev G.E. Selektsiia rastenii v SShA. [Plant breeding in the United States]. Moscow, 1976, 349 p. (in Russ.).

Received May 21, 2015

Revised September 20, 2015

\footnotetext{
* Corresponding author.
} 